\title{
CHARACTERISTICS OF DISSOLVED ORGANIC NITROGEN IN MUNICIPAL AND BIOLOGICAL NITROGEN REMOVAL WASTEWATER TREATMENT PLANTS IN JORDAN
}

\author{
Mohammed Ali WEDYAN *, Esam QNAIS *, Khalil ALTAIF ** and Abdel AL-TAWAHA *** \\ * The Hashemite University, Biological Sciences and Biotechnology Department, Az-Zarqa, P. O. Box \\ 330127, Jordan, mwedyan@hu.edu.jo, Esamqn@hu.edu.jo \\ ** Middle East University, Faculty of Pharmacy, Amman, P. O. Box 123, Jordan, kialtaif@yahoo.com \\ *** Al Hussein Bin Talal University, Maan, P. O. Box 20, Jordan, abdeltawaha@yahoo.com
}

DOI: 10.2478/trser-2019-0008

KEYWORDS: nitrogen fractionation, amino acids, wastewater treatment plants.

\section{ABSTRACT}

The investigation is conducted on the biochemical form and characteristics of wastewater-derived DON in three different WWTPs in Jordan. The main eliminations of DON and biodegradable dissolved organic nitrogen (BDON) noticed along the treatment course are in the Irbid (ITP). Dissolved combined amino acids (DCAA) and dissolved free amino acids (DFAA) in the outlet accounted for less than $4 \%$ of the outlet DON of all plants. The DON from the outlet was composed of $90 \%$ hydrophilic compounds which stimulate algal growth. The study provided information for future improvement of WWTPs of Jordan and for adjusting the assortment of DON elimination systems to comply with stricter limits.

RÉSUMÉ: Caractéristiques de l'azote organique dissous dans les usines municipales de traitement des eaux usées par enlèvement biologique de l'azote en Jordanie.

La forme biochimique et les caractéristiques du DON dérivé des eaux usées dans trois WWTP différentes en Jordanie ont été étudiées. Les principal éliminations de DON et d'azote organique dissous (BDON) biodégradable tout au long du traitement ont été observées à Irbid (ITP). Les acides aminés combinés dissous (DCAA) et les acides aminés libres dissous (DFAA) dans l'exutoire représentaient moins de 4\% du DON de toutes les usines. Plus de $90 \%$ du DON émis était sous forme de composés hydrophiles qui stimulent la croissance des algues. L'étude a fourni des informations pour l'amélioration future des stations d'épuration de la Jordanie et pour l'assortiment de systèmes d'élimination de DON pour respecter des limites de décharge d'azote plus basses.

REZUMAT: Caracteristicile azotului organic dizolvat în staţiile municipale de tratare a apei uzate cu treaptă biologică pentru eliminarea nitraților din Iordania.

Au fost analizate forma biochimică și caracteristicile DON provenit din apa uzată în trei WWTP din Iordania. Cele mai importante eliminări ale DON și azotului organic dizolvat biodegradabil (BDON) în timpul procesului de tratare au fost constatate la Irbid (ITP). Aminoacizii combinaţi dizolvați (DCAA) și aminoacizii liberi dizolvați (DFAA) din emisar au însumat aproximativ sub 4\% din DON deversat pentru toate staţiile. Peste 90\% din DON deversat a fost format din compuși hidrofili care stimulează dezvoltarea algală. Studiul oferă informații pentru viitoare îmbunătățiri ale WWTPs iordaniene și pentru ajustarea sistemelor de eliminare a DON pentru a respecta limite mai stricte de azot în emisar. 


\section{INTRODUCTION}

Pollution is one of the main human negative impact on water qality (Sandu et al., 2008; Yildiz et al., 2010; Akkoz, 2016; Al-Rufaie, 2016; Khoshnood, 2017). The most significant source of anthropogenic nitrogen to surface waters is the domestic wastewater runoff that also has distinct effects on the water quality, especially in effluent-dominated waters (Pagilla et al., 2008; Bronk et al., 2010; Liu et al., 2012; Huo et al., 2013). Biological enhanced nitrogen removal (BENR) processes that eliminate most of the dissolved inorganic nitrogen are widely used in the domestic wastewater treatment to decrease cultural eutrophication of the reception waters (Czerwionka et al., 2012). The dissolved organic nitrogen (DON) is one of the remaining fractions of nitrogen in the outlet of the effective BENR process that influence the surface water (Pagilla et al., 2006; Liu et al., 2012) Previous studies showed that algae and plankton are sensitive to the bio available DON of the outlet (Pehlivanoglu-Mantas and Sedlak, 2006, 2008; Sattayatewa et al., 2009; Simsek et al., 2013). Nowadays, DON is currently important in wastewater treatment plants (WWTPs) because of highly concerns such as increase and stimulate algal growth (Pehlivanoglu-Mantas and Sedlak, 2004) and forming nitrogenous compounds by-product $\mathrm{N}$-nitrosodimethylamine (PehlivanogluMantas and Sedlak, 2006, 2008; Lee et al., 2007). The emerging worries for wastewaterderived DON have augmented the requirement to define their concentrations, structure and properties.

DON is commonly determined by subtracting dissolved inorganic nitrogen (DIN, the sum of ammonium, nitrate and nitrite) concentrations from the total dissolved nitrogen (TDN) concentrations. Low DON concentration quantification in waters with high DIN/TDN ratio using existing methods tends to be inaccurate and DON measurements often have high standard deviations. (Lee et al., 2007) Some pre-treatment methods were used to increase the accuracy and precision of DON quantities, (Lee el al., 2007) and nanofiltration (NF) pre-treatment (Xu et al., 2010). The limitations of available measurement methods dissatisfied investigators considering the nature and behaviour of DON in wastewater treatment plants. As a substitute to measuring DON as a bulk parameter in wastewater, investigators have measured specific organic nitrogen containing compounds such as dissolved free and combined amino acids (DFAA and DCAA). (Pehlivanoglu-Mantas and Sedlak, 2008) To characterize the unidentifiable wastewater-derived DON, the molecular weight (MW) distributions of DON are also measured. Most studies presented that about $70 \%$ of wastewater-derived DON still cannot be considered with currently available methods. (Pehlivanoglu-Mantas and Sedlak, 2006, 2008; Simsek et al., 2012)

Previous studies on wastewater-derived DON focused on two important research enquiries: where DON is removed or produced in BERN processes and what is the effect of BERN process on DON (Czerwionka et al., 2012; Simsek et al., 2013). Sattayatewa et al. (2009) informed that about 28-57\% of the effluent DON was bio available or biodegradable by using diverse kinds of test species.

The present study aimed to get more information on wastewater-derived DON in wastewater treatment plants and to assess the concentrations of amino acids in wastewaters without sample pre-concentrating. We measured the concentration and removal percentage of both forms of amino acids (DFAA and DCAA) at dissolved organic nitrogen and bio available dissolved organic nitrogen in triggered sludge and trickling filter wastewater from treatment processes. 


\section{MATERIAL AND METHODS}

\section{Sample sources}

Samples were obtained from three different treatment plants effluent, which are AlZarqa (ZTP), Irbid (ITP), and al Mafraq (MTP) (Fig. 1). The selected plants treat about $90 \%$ of the domestic wastewater in Jordan and serve more than two million inhabitants (Bataineh et al., 2002); the treatment process is in table 1.

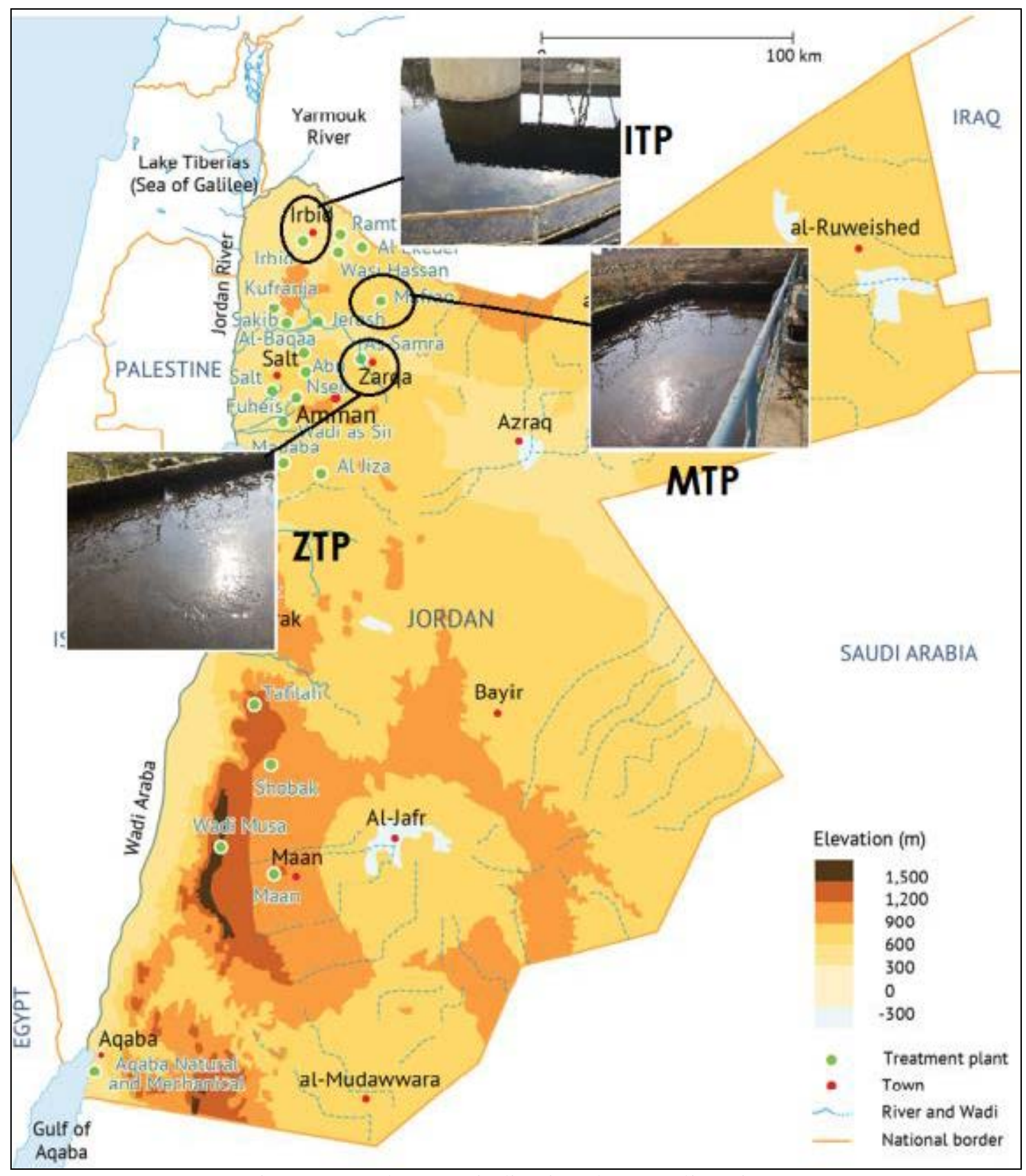

Figure 1: Jordan map indicating the sampling sites. 
Table 1: The treatment plants concerned in the study (Bataineh et al., 2002).

\begin{tabular}{|c|c|c|}
\hline Plant & Treatment process & Remarks \\
\hline Al-Zarqa & $\begin{array}{l}\text { Stabilization ponds } \\
\text { aeration, facultative }\end{array}$ & \\
\hline Irbid & $\begin{array}{l}\text { Screen, grit removal, primary sedimentation, biological } \\
\text { process, secondary sedimentation, disinfections }\end{array}$ & $\begin{array}{l}\text { Trickling filter and } \\
\text { activated sludge }\end{array}$ \\
\hline Mafraq & $\begin{array}{l}\text { Screen, grit removal, biological process, secondary } \\
\text { sedimentation, polishing pond, infiltration, } \\
\text { disinfections }\end{array}$ & $\begin{array}{l}\text { Activated sludge } \\
\text { with nitrogen } \\
\text { removal technique }\end{array}$ \\
\hline
\end{tabular}

All plants must adhere to discharge limits for biochemical oxygen demand (BOD) and ammonia (based on the receiving river flow rate) but are not subject to any total nitrogen or total phosphorus limits.

\section{Collection and preparation}

The samples are from the wastewater treatment plants collected on three different dates, specifically February, April and June of 2015. All samples were collected in polyethylene containers (acid-washed and rinsed with ultrapure water) (Mill-Q, Millipore Corp. USA), then delivered to the laboratory on ice, filtered through $0.45 \mu \mathrm{m}$ cellulose acetate membranes upon arrival, and stored at $4^{\circ} \mathrm{C}$ in the dark according to Huo et al. (2013).

\section{DFAA and DCAA determination procedures}

To prevent contamination by laboratory controls, pre-cleaned glassware, which include filters, were used in all laboratory work. The glassware was prepared by washing in alkaline detergent, placing in $1 \mathrm{~N} \mathrm{HCl}$ overnight followed by rinsing with organic free water obtained with distilled water and then heating in an oven at $110^{\circ} \mathrm{C}$ for 10 to $12 \mathrm{~h}$ according to Wedyan and his colleagues (Wedyan et al., 2008). To identify the amino acids in rainwater, samples filter through $0.45 \mu \mathrm{m}$ cellulose acetate filters then are kept at $5^{\circ} \mathrm{C}$ until analysis. All samples are run in triplicates.

The amino acids in the samples are separated into the following fractions (i) the dissolved free amino acids (DFAA) (i.e. those uncombined amino acids directly extractable into water), (ii) the dissolved hydrolysable amino acids (DHAA) (i.e. those combined amino acids directly extractable into water and released by hydrolysis), (iii) total dissolved amino acids (DTAA = DFAA - DHAA).

The recovery of 14 individual amino acids spiked into water prior to the hydrolysis step ranged between 92.1 and $99.3 \%$. All analyses were carried out in triplicate for each sample according to Huo et al. (2013) modified the high amplitude. 


\section{RESULTS AND DISCUSSION}

The variations of DON in each plant were studied in previous work and presented in table 2 (Wedyan et al., 2016).

Table 2: Concentration (mg-N/L) of Dissolved Nitrogen in Different locations, (average \pm SD) (Wedyan et al., 2016).

\begin{tabular}{|l|c|c|c|}
\hline \multicolumn{1}{|c|}{ Dissolved Nitrogen } & ZTP & ITP & MTP \\
\hline $\mathrm{DNO}_{3} \mathrm{~N}$ & $6.81 \pm 2.40$ & $6.33 \pm 3.80$ & $7.83 \pm 6.49$ \\
\hline $\mathrm{DNO}_{2} \mathrm{~N}$ & $0.48 \pm 0.040$ & $0.70 \pm 0.048$ & $0.013 \pm 0.002$ \\
\hline $\mathrm{DNH}_{4} \mathrm{~N}$ & $0.039 \pm 0.0030$ & $0.70 \pm 0.48$ & $0.06 \pm 0.019$ \\
\hline $\mathrm{DTN}$ & $19.30 \pm 6.60$ & $41.8 \pm 3.39$ & $33.21 \pm 5.01$ \\
\hline $\mathrm{DNO}_{3} \mathrm{~N}$ & $6.81 \pm 2.40$ & $6.33 \pm 3.80$ & $7.83 \pm 6.49$ \\
\hline
\end{tabular}

As shown in table 2, average DON concentrations in ZTP, ITP and MTP influent ranged from 0.039 to $33.21 \mathrm{mg} \mathrm{l}^{-1}$ as $\mathrm{N}$. The results of this study are consistent with the concentration range previously reported in BENR plant effluents (Pagilla et al., 2006; Pehlivanoglu-Mantas and Sedlak, 2008; Sattayatewa et al., 2009; Czerwionka et al., 2012; Huo et al., 2013).

Pehlivanoglu-Mantas and Sedlak, (2008) propose that DON was challenging to eliminate during biological treatment. The information regarding the biodegradable portion of the DON (BDON) profile along the treatment train will help recognize the roles of the wastewater treatment process in the removal of this fraction of DON (Simsek et al., 2013 Huo et al., 2013).

\section{Distribution of dissolved free (DFAA) and combined amino acids (DCAA).}

Measurements on the distribution of DFAA and DCAA concentrations are from the treatment of ZTP, ITP and MTP samples to obtain information of the composition of inlet and outlet dissolved amino acids (DAA) and the effect of treatment processes on DFAA and DCAA (Figs. 2a-d).

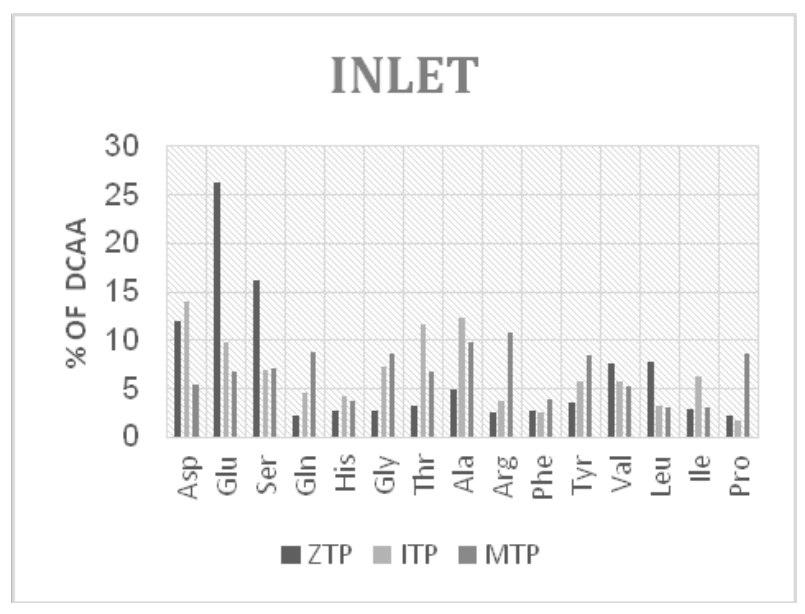

Figure 2a: DFAA and DCAA concentrations percentages of ZTP, ITP and MTP samples (inlet and outlet). 


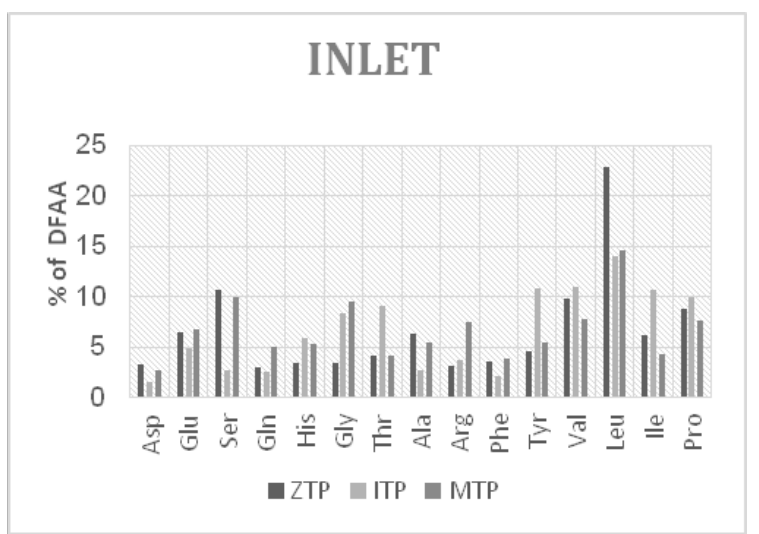

Figure 2b: DFAA and DCAA concentrations of ZTP, ITP and MTP samples (inlet and outlet).

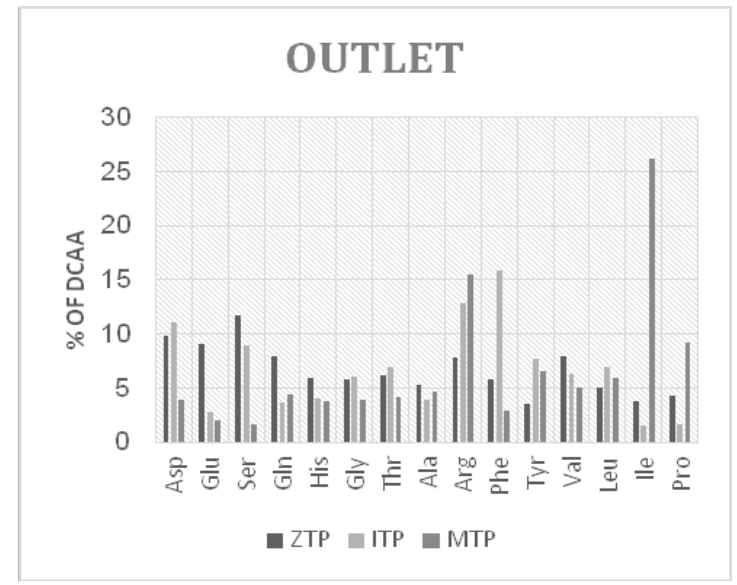

Figure 2c: DFAA and DCAA concentrations of ZTP, ITP and MTP samples (inlet and outlet).

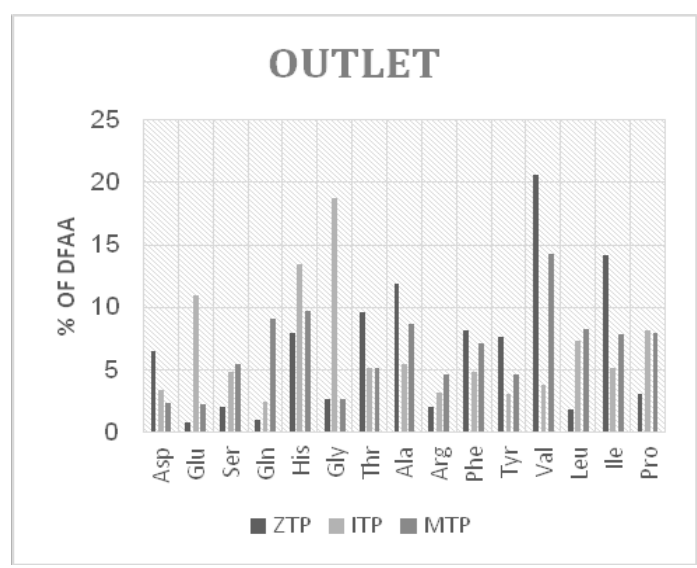

Figure 2d: DFAA and DCAA concentrations of ZTP, ITP and MTP samples (inlet and outlet). 
Figures 2a-d, show both concentrations of inlets and outlet in the wastewater treatment plants of DFAA and DCAA values. The reduction of the proportion levels of the DFAA and DCAA along the treatment by $56 \%$ and $63 \%$, respectively. While the DCAA concentrations ranged from 7.35 to $16.6 \mu \mathrm{M}$ in the inlet and ranged from 0.79 to $5.88 \mu \mathrm{M}$ in the outlet that covering for $2.27-4.42 \%$ of the inlet DON and $1.72-6.40 \%$ of the outlet DON, respectively. And also the DFAA contributed about $0.1-0.62 \%$ of DON in the inlet and about $0.61-0.97 \%$ of outlet. The results show that the DCAA proportions in the different plants in Jordan showed a significantly higher than DFAA proportions.

The DFAA and DCAA concentration measurements are from different locations in the studied WWTPs (Fig. 3). The DFAA concentration ranged from 0.011 to $0.071 \mu \mathrm{l} / \mathrm{ml}$ in the inlet, and from 0.0018 to $0.06 \mu \mathrm{l} / \mathrm{ml}$ in the outlet, whereas the concentration of DCAA ranged from 0.038 to $4.85 \mu \mathrm{l} / \mathrm{ml}$ in the inlet, and from 0.038 to $0.77 \mu \mathrm{l} / \mathrm{ml}$ in the outlet. It was also found that the concentration of DFAA in ZTP, ITP and MTP inlets were $0.73 \pm 0.015,0.71 \pm 0.014$ and $0.72 \pm 0.015 \mu \mathrm{l} / \mathrm{ml}$ respectively. In contrast, the concentration of DCAA in ZTP, ITP and MTP inlets were $4.67 \pm 0.97,6.67 \pm 1.06$ and $5.08 \pm 0.58 \mu \mathrm{l} / \mathrm{ml}$ respectively. To compare this with the outlets treated wastewater it was found that the concentration of DFAA in ZTP, ITP and MTP were $0.33 \pm 0.15,0.31 \pm 0.14$ and $0.39 \pm 0.21 \mu \mathrm{l} / \mathrm{ml}$ respectively, and the concentration of DCAA in ZTP, ITP and MTP were $2.28 \pm 0.1,2.45 \pm 0.14$ and $2.95 \pm 0.18 \mu \mathrm{l} / \mathrm{ml}$ respectively. The DCAA concentration differs by an average of $18 \%$ over the course of treatment between the different plants, whereas the DFAA differs by an average of $1.4 \%$ only. The removal ratios of DFAA varied between plants with values of around $56 \%$ at ZTP, $52 \%$ at ITP and $45 \%$ at MTP, and that seems to depend on the treatment used. The removal ratios of DCAA were varied between plants as well with values of around $51 \%$ at ZTP, $63 \%$ at ITP and $42 \%$ at MTP.

The concentrations of DFAA and DCAA in the inlets of all WWTPs were within ranges reported in previous studies (Parkin and McCarty, 1981; Confer et al., 1995; Grohmann et al., 1998; Dignac et al., 2000). Supposing a characteristic DON concentration of $143 \mu \mathrm{M}$ $\left(\sim 2.0 \mathrm{mg} \mathrm{N} \mathrm{I}^{-1}\right)$ in the wastewater inlets, the DFAA concentration accounted for between 0.3 and 3\% of the DON, while the DCAA accounted for 1.5-13\% of the DON (Parkin and McCarty, 1981; Confer et al., 1995; Dignac et al., 2000). The comparatively low concentrations of DCAA and DFAA in the inlet samples most likely formed during biological treatment since amino acids and proteins are readily removed by microorganisms (Confer et al., 1995; Pehlivanoglu-Mantas and Sedlak, 2008).

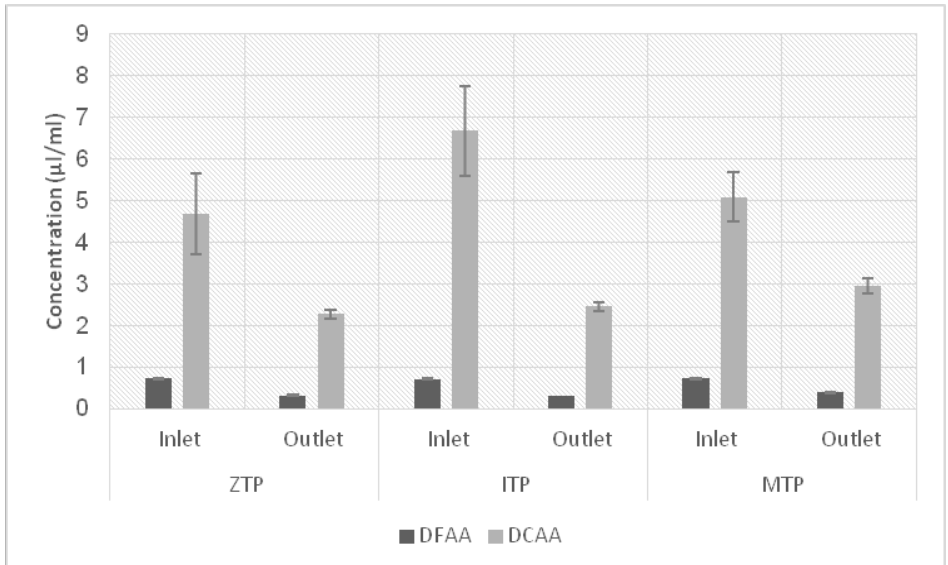

Figure 3: Concentration of DFAA and DCAA at the wastewater treatment plants $(\mu \mathrm{l} / \mathrm{ml})$. 
While most of the wastewater-derived DON cannot be recognized with accessible methods ( 70\%) (Pehlivanoglu-Mantas and Sedlak, 2008), DON can be categorized by its molecular weight (MW). Pagilla and his colleagues (2008) suggested that the low molecular weight DON fractions with less than one $\mathrm{kDa}$ are urea, amino acids, DNA, peptides and various artificial compounds and that the DON group with more than one $\mathrm{kDa}$ are composed of fulvic acids and humic substances. Biological nitrogen removal processes, for example, the activated sludge process, have been viewed as successful in expelling low sub-atomic weight DON, while high MW DON is viewed as recalcitrant to this sort of treatment (Dignac et al., 2000; Pagilla et al., 2008). However, the results of DON molecular weight distributions at the three studied WWTPs and in this study indicated that about half of the DON can go through a one kDa ultra filter, and low MW DON cannot successfully be detached by the biological nitrogen removal processes or the membrane biological removing process (MBR). Shon et al. (2005) found that microfiltration or nanofiltration may not be very good in eliminating wastewater-derived DON due to the polluting problems often met in micro and/or nanofiltration. This research highlight that the low MW DON fractions probable appeared concurrently with the biological treatment. This research also found that the DON concentrations raised in the oxic zone as explained above. Consequently, the conditions and processes responsible for low MW DON production need additional studies. Suitable operating conditions or treatment processes should be employed to decrease effluent low molecular weight DON to inferior levels.

\section{Hydrophobicity of outlet}

The estimated outlet percentage of DON was separated into hydrophobic and hydrophilic fractions. The overall recovery of DON in the two fractions ranged from $91.3 \%$ to $97 \%$, with an average of $94.7 \pm 0.9 \%$. The hydrophobic DON accounted for an average of 1.11 $\pm 0.01 \%$ of the total DON in the outlet samples of ZTP (Fig. 4), and an average of $1.07 \pm 0.02 \%$ of the total DON in the outlet samples of ITP (Fig. 4) and an average of $0.88 \pm 0.02 \%$ of the total DON in the outlet samples of MTP. The results of this study found that most DON fractions were hydrophobic compounds, which was similar to the previous studies. (Pehlivanoglu-Mantas and Sedlak, 2008; Liu et al., 2012) All the studies proposed that the hydrophobic fractions would be much more easily removed by adsorption of activated sludge in the biological treatment systems, while the hydrophilic compounds have a low attraction for the surfaces of organic particles (Pehlivanoglu-Mantas and Sedlak, 2008). Furthermore, the C:N ratios of the hydrophobic fraction and hydrophilic fraction were $11.4 \pm 0.2,15.7 \pm 2.3$ and 11.8 \pm 0.9 in this study. The hydrophilic fractions have low $\mathrm{C}: \mathrm{N}$ ratios representative the presence of amino acids and proteins, which result in N-rich hydrophilic fractions. (Leenheer et al., 2007) Some studies suggested that bioavailability of hydrophobic and hydrophilic DON by the algal bioassay tests, the results showed that hydrophilic DON, which accounted for around $80 \%$ of the waste DON, encouraged algal growth, whereas the remaining DON as hydrophobic DON had no effect on algal growth during a 14-day incubation period Liu et al. (2012). Thus, the hydrophobic DON may be measured to eliminate from the outlet total nitrogen principles, while hydrophilic DON in wastewater treatment plants with different biological nutrient removal (BNR) processes might be compact by using alternative biological treatment systems such as reverse osmosis, activated carbon adsorption (Krasner et al., 2009). 


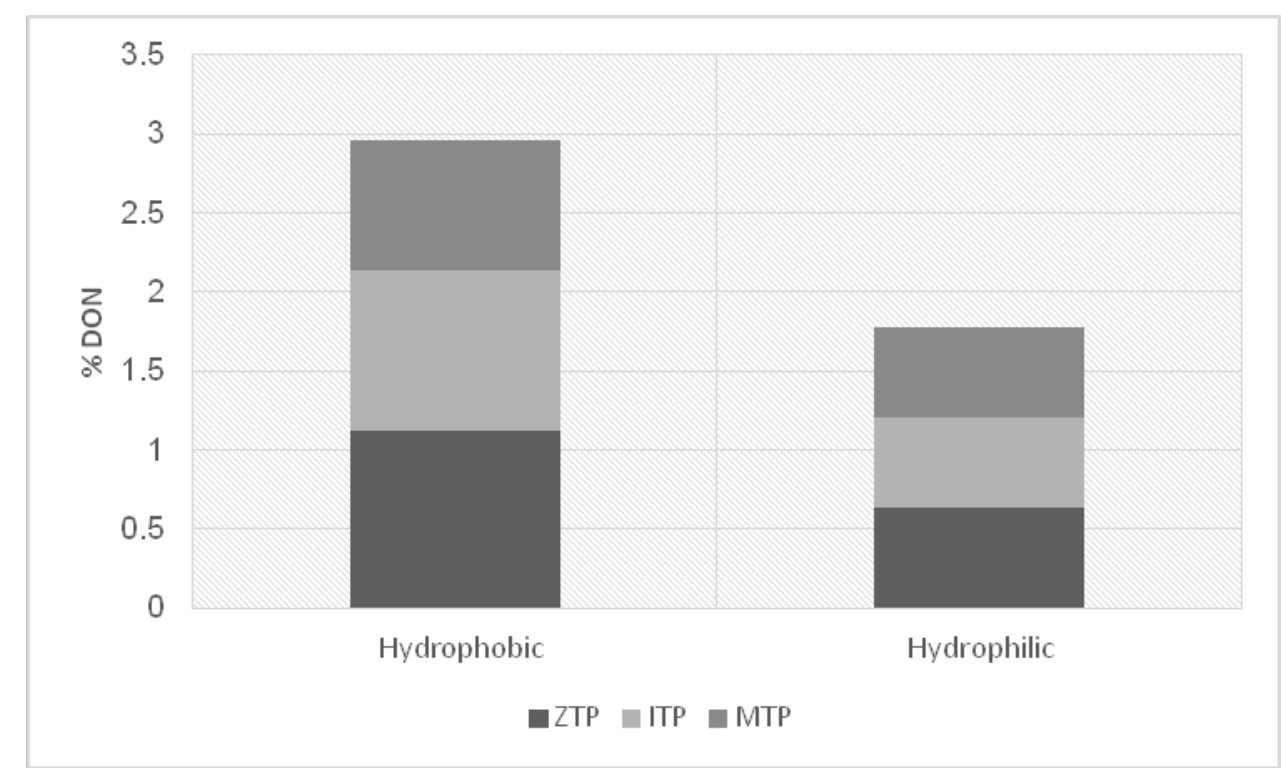

Figure 4: Hydrophobic and hydrophilic fractions of outlet DON.

\section{CONCLUSIONS}

This research supply a valuable image of the occurrence and treatment of DON in WWTPs. The dominant removal fractions of DON and biodegradable dissolved organic nitrogen (BDON) along the treatment progress were noticed in the Irbid (ITP). Dissolved combined amino acids (DCAA) and dissolved free amino acids (DFAA) in the outlet accounted approximately for less than $4 \%$ of the outlet DON of all plants. Over $90 \%$ of outlet DON was composed of hydrophilic compounds which provoke algal growth. The research offer important data for planned improving of WWTPs of the studied area and for the preference of DON removal systems to meet greater demanding nitrogen discharge limits. 


\section{ACKNOWLEDGEMENTS}

This research was supported by Deanship of Research, The Hashemite University. 


\section{REFERENCES}

1. Akköz C., 2016 - The determination of some pollution parameters, water quality and heavy metal concentrations of Aci Lake (Karapinar/Konya, Turkey), Transylvanian Review of Systematical and Ecological Research, The Wetlands Diversity, 18.3, 1-20.

2. Al-Rufaie M. M., 2016 - Measuring the extent of the environmental pollution in the waters of the Al-Diwani River by certain trace elements resulting from Al-Diwani textile factory using spectroscopic methods, Transylvanian Review of Systematical and Ecological Research, The Wetlands Diversity, 18.1, 69-86.

3. Bataineh F., Najjar M. and Malkawi S., 2002 - Water Demand Forum, Wastewater Reuse Report, Beirut, Lebanon, 257.

4. Bronk D. A., Roberts Q. N., Canuel E. A., Mesfioui R., Filippino K. C., Mulholland M. R. and Love N. G., 2010 - Effluent organic nitrogen bioavailability and photochemical and salinitymediated release, Environmental Science and Technology, 445830-445835.

5. Confer D. R., Logan B. E., Aiken B. S. and Kirchman D. L., 1995 - Measurement of dissolved free and combined amino acids in unconcentrated wastewaters using high performance liquid chromatography, Water Environment Research, 67118-1256.

6. Czerwionka K., Makinia J., Pagilla K. R. and Stensel H. D., 2012 - Characteristics and fate of organic nitrogen in municipal biological nutrient removal wastewater treatment plants, Water Research, 462057-462066.

7. Dignac M. F., Ginestet P., Ryback D., Bruchet A., Urbain V. and Scribe P., 2000 - Fate of wastewater organic pollution during activated sludge treatment: nature of residual organic matter, Water Research, 344185-344194.

8. Grohmann K., Gilbert E. and Eberle S. H., 1998 - Identification of nitrogen-containing compounds of low molecular weight in effluents of biologically treated municipal wastewater, Acta Hydrochimica et Hydrobiologica, 2620-2630.

9. Huo S. L., Xi B. D., Yu H., Qin Y. W., Zan F. Y. and Zhang J. T., 2013 - Characteristics and transformations of dissolved organic nitrogen in municipal biological nitrogen removal wastewater treatment plants, Environemtal Research Letters, 8, 0440050440059.

10. Khoshnood Z., 2017 - Effects of environmental pollution on fish: a short review, Transylvanian Review of Systematical and Ecological Research, The Wetlands Diversity, 19.1, 49-60.

11. Krasner S. W., Westerhoff P., Chen B., Rittmann B. E., Nam S. N. and Amy G., 2009 - Impact of wastewater treatment processes on organic carbon, organic nitrogen, and DBP precursors in effluent organic matter, Environmental Science and Technology, 43, 2911-2918.

12. Lee W., Westerhoff P. and Croues J. P., 2007 - Dissolved organic nitrogen as a precursor for chloroform, dichloroacetonitrile nitrosodimethylamine, and trichloronitromethane, Environmental Science and Technology, 415485-415490.

13. Leenheer J. A., Dotson A. and Westerhoff P., 2007 - Dissolved organic nitrogen fractionation, Annals of Environmental Science, 45-56.

14. Liu H. Z., Jeong J., Gray H., Smith S. and Sedlak D. L., 2012 - Algal uptake of hydrophobic and hydrophilic dissolved organic nitrogen in effluent from biological nutrient removal municipal wastewater treatment systems, Environmental Science and Technology, 46713-46721.

15. Pagilla K. R., Czerwionka K., Urgun-Demirtas M. and Makinia J., 2008 - Nitrogen species in wastewater treatment plant influents and effluents-the US and Polish case studies, Water Science and Technology, 571511-571517.

16. Parkin G. F. and McCarty P. L., 1981 - A comparison of the characteristics of soluble organic nitrogen in untreated and activated-sludge treated wastewaters, Water Research, 15139-15149.

17. Pehlivanoglu-Mantas E. and Sedlak D. L., 2006 - The fate of wastewater-derived NDMA precursors in the aquatic environment, Water Research, 401287-401293.

18. Pehlivanoglu-Mantas E. and Sedlak D. L., 2008 - Measurement of dissolved organic nitrogen forms in wastewater effluents: concentrations, size distribution and NDMA formation potential, Water Research, 423890-423898. 
19. Sandu C., Bloesch J. and Coman A., 2008 - Water pollution in the Mureş, Catchment and its impact on the aquatic communities (Romania), Transylvanian Review of Systematical and Ecological Research, The Wetlands Diversity, 6, 97-108.

20. Sattayatewa C., Pagilla K., Pitt P., Selock K. and Bruton T., 2009 - Organic nitrogen transformations in a four-stage Bardenphonitrogen removal plant and bioavailability/biodegradability of effluent DON Water Research, 434507-434516.

21. Shon H. K., Vigneswaran S., Ben Aim R., Ngo H. H., Kim I. S. and Cho J., 2005 - Influence of flocculation and adsorption as pretreatment on the fouling of ultrafiltration and nanofiltration membranes: application with biologically treated sewage effluent, Environmental Sciences and Technolology, 393864-393871.

22. Simsek H., Kasi M., Ohm J. B., Blonigen M. and Khan E., 2013 - Bioavailable and biodegradable dissolved organic nitrogen in activated sludge and trickling filter wastewater treatment plants, Water Research, 473201-473210.

23. Simsek H., Kasi M., Ohm J. B., Wadhawan T., Bye C., Blonigenm M. and Khan E., 2012 - Fate of dissolved organic nitrogen in two stage trickling filter process, Water Research, 465115465115.

24. Wedyan M. A. and Preston M. R., 2008 - The coupling of surface seawater organic nitrogen 538 and the marine aerosol as inferred from enantiomer-specific amino acid analysis, 539, Atmospheric Environment, 42, 8698-8705.

25. Wedyan M., Al Harahsheh A. and Qnais E., 2016 - Determination of the Fate of Dissolved Organic Nitrogen in the Three Wastewater Treatment Plants, Jordan, International Journal of Environmental and Science Education, 11, 6, 767-777.

26. Yildiz F. E., Ünsal N. and Gürer I., 2010 - Water pollution at Sultansazligi Wetland and Develi closed basin (Turkey), Transylvanian Review of Systematical and Ecological Research, The Wetlands Diversity, 10, 169-184. 